\title{
Cultural Reflection on Ideological and Political Education in Universities under the Background of Popular Culture
}

\author{
Shunqi Gao \\ College of Marxism, Guangdong Industry polytechnic, Guangzhou Guangdong, 510300, China
}

Keywords: Popular culture, Ideological and political education, Colleges and universities.

\begin{abstract}
The mass culture has a double impact on the ideological and political education of college students. Under the background of popular culture, the ideological and political education of college students should be reformed and reformed. The actual situation of popular culture background should be fully considered, and the ideological and political education should be interpreted from the cultural point of view , And then put forward the corresponding ideological and political education strategies, the ideological and political quality of students to be cultivated for the future development of students to provide an important guarantee. This paper starts from the dual influence of the current popular culture on the ideological and political education of the university, and makes an appropriate analysis to the organization 's ideological and political education measures, hoping to provide good support for the reform and development of the ideological and political education in the university.
\end{abstract}

\section{Introduction}

Popular culture is one of the important cultural basic models, is the process of industrial society in the development of urban public consumption formed by the party and government media, no depth, easy to copy, according to the specific market rules for mass production Of cultural products. In the contemporary society, the popular culture in the development process shows obvious commodity, reproduction, central characteristics, and the mass culture to show a clear tendency to the university. Therefore, it is necessary to study and analyze the ideological and political education of college students in the new period, to carry out cultural thinking on ideological and political education, and to formulate more scientific and rational ideological and political education measures to provide comprehensive improvement of educational quality. Good support.

\section{The Double Influence of Popular Culture Background on the Formation of College Students' Ideology}

In the current social background, the mass culture has shown a clear tendency to integrate into the ideological development of college students, and the popular culture in the development process can have a specific impact on the ideological and political education of college students, the following from the perspective of dual impact on the public An Analysis of College Students' Ideology in the Context of Culture.

\section{The Positive Influence of Popular Culture on College Students' Ideology}

The mass culture has gradually accelerated the process of industrialization, the modernization of the new achievements, the market economy to deepen the development of the gradual development of the cultural model, the mass culture itself shows a strong equality, openness, competition and cooperation characteristics, with modern value pursuit of development tendencies The In college students gradually contact with the vast expanse of cultural works in the process, will inevitably be influenced by the public culture, and the positive elements of popular culture can also have a positive 
impact on the ideological ideas of college students. On the one hand, in the context of popular culture, college students can gradually form an independent personality [1]. Public culture has a high degree of attention to the participation of the audience, and in the public participation in mass cultural activities in the process will be appropriate to communicate and exchange, audience independence and equality will be further highlighted. As an important part of the mass culture audience, the highlight of independence and equality in the process of communication can help the formation of college students 'subjectivity, and have an important influence on the growth of college students' independent personality. On the other hand, mass culture can have an important impact on the formation of students' multicultural values. Under the background of pluralistic popular culture, college students 'choice of culture is no single and limited, but can accept all kinds of culture, which is very important to the highlight of college students' cultural inclusiveness. In addition, the popular culture in the cultivation of students active and healthy state of mind also play a vital role. The popular culture contains a certain number of entertaining works, and these entertaining cultural contents have an important impact on the students' lifestyles, can effectively relieve the students' mental stress, promote the balance of students' mental state, and ensure that students can adapt quickly to the current Complex and changeable modern life, in the new period to obtain stable development.

\section{The Negative Influence of Popular Culture on College Students' Ideology}

Mass culture has obvious commodity attributes, and its commodity attributes above the cultural attributes, in the mass culture of the long process of development, it has been the object of competition for profit activities, so the impact of adverse effects of market economy, mass culture in the The development process will often have a negative impact on the ideological ideas of college students. First of all, the public culture shows obvious business attributes, to a certain extent, cause college students group values are too impetuous, is not conducive to the healthy growth of college students. In the current mass culture background, by the deepening of the development of the market spirit of the impact of economic efficiency objectives still occupy an extremely important position, the popular culture in the development process too much emphasis on gorgeous packaging, ideological value is too flat, do not attach importance to deep thinking, and There is against the lofty atmosphere [2]. The existence of these problems to a certain extent, the impact of college students by the public culture in life is difficult to calm down to look at themselves, thinking about life is not conducive to the good development of college students' ideological values. Secondly, the multiculturalism in the field of mass culture can easily lead to the development of college students' ideological values. The core of culture is values, and culture is the most intuitive expression of values. In the context of the vigorous development of the current popular culture, the diversified ideological value of the pursuit of people's ideas have a huge impact on the students' outlook on life and values in the formation of the period, and by the impact of multiculturalism, students are difficult Culture to form the correct judgments, leading to the establishment of ideological values in the process of students tend to appear confusion in the situation, the development of students had a serious adverse effects. Finally, the mass culture shows obvious duplication, resulting in college students' values have obvious obscure characteristics. The development of mechanization and industrialization not only provides a large number of mass cultural products for the community. In essence, the development of these popular cultural products has also resulted in the emergence of a large number of replicas. Students are in a difficult way to get into mechanization in contact with a large number of replicas , Gradually lost the ability to think, the formation of personalized thinking of college students had a negative impact, but also limited the cultivation of college students and creative ability.

\section{Measures of Reform and Innovation of College Students' Ideological and Political Education under the Background of Popular Culture}

Based on the current popular cultural background, colleges and universities in the process of implementing ideological and political education of college students should be combined with the 
impact of mass culture on the ideological values of college students to conduct a specific analysis, and then actively explore the corresponding reform measures to effectively promote the ideological and political education level, For the good development of college students to provide comprehensive support and guidance to promote the ideological and political achievements of college students to obtain.

\section{Exploring the Complementation of Ideological and Political Education and College Students' Self - education}

The traditional ideological and political education in colleges and universities as a major work of ideological and political theory as the main work, to instill the ideological and political theory of educated knowledge, hope that students can rely on the accumulation of ideological and political knowledge to gradually improve their overall quality and get good development. However, this kind of education mode has already shown obvious drawbacks in the course of long-term development, and it is imperative to carry out reform and innovation of ideological and political education [3]. In this context, the ideological and political education workers in colleges and universities gradually recognize the importance of self-education, hoping to students with self-education to achieve self-development and self-improvement, so that students in the process of growth can really know themselves, And then make the most correct choice. Based on this, in the context of the current popular culture of public culture, because the mass culture background will be the world outlook, outlook on life and values are not yet mature college students group ideas have an important impact, so in the process of ideological and political education, colleges and universities should be positive To tap the popular cultural elements that can positively influence the ideology of college students, and then to guide students to learn from the valuable, able to obtain the relevant knowledge of the popular culture, to promote the rich and development of student personality, make full use of the positive impact of popular culture to promote student participation in democracy And the realization of individual values. In the practice of specific education and teaching, ideological and political teachers must change the traditional teaching concept, the students as the main body of teaching activities in the teaching activities and students to communicate and communicate with each other, and students to form a mutual understanding of mutual trust, Students to implement targeted education and guidance to guide students in the process of development to examine themselves, think about themselves, clear their own internal development needs, and then rational use of public culture to enhance their overall quality for college students in the development and growth of modern society to provide important Guarantee. Only then can we really play a positive role in the popular culture, mass culture under the background of the quality of ideological and political education can also achieve further enhance.

\section{Actively promote the mutual penetration of explicit education and recessive education}

The explicit education is an important channel for the implementation of quality education in colleges and universities. It can organize and plan the teaching contents under the guidance of clear teaching objectives, and carry out targeted education and guidance to students and promote the improvement of the quality of education. But in the current mass culture background, colleges and universities in order to achieve the comprehensive quality of college students to cultivate, but also should further strengthen the importance of hidden education, and actively explore the hidden, but also to improve the overall quality of students, Sex education optimization measures, in the sex education gradually penetrate the hidden cultural elements of education, with the support of hidden education continue to innovation in education, to achieve the hidden education and explicit education of the coordinated development, and then with the Reasonable integration to promote the ideological and political education of college students to obtain the effectiveness of the subjectivity and autonomy of college students to provide comprehensive support. In the practice of specific education, on the one hand, colleges and universities can use the mass media technology, combined with the positive influence elements in the mass culture to enable students to carry out explicit education, so that students can gradually form a correct understanding of ideas and guide students to healthy growth. Such as the 
education staff can fully use the campus to paste it, micro-public platform and weibo service platform to publish relevant information to college students, the dissemination of active mass culture, the gradual popularization of mass culture into college students ideological and political education, to promote the ideological and political education of college students influence And inactivity has been significantly enhanced for the ideological and moral quality of college students to provide an important guarantee [4]. On the other hand, in the process of carrying out recessive education, colleges and universities should fully excavate the elements and contents of hidden culture in popular culture, and then play the implicit influence of recessive education and promote the gradual formation of correct ideological values, For the students the right view of life, the establishment of values to provide an important guarantee. If the school regularly organize students to watch "when the happiness to knock on the door" type of inspirational film, students in the process of watching the film can be affected by the implicit education ideas, the effectiveness of ideological and political education is bound to be further enhanced.

\section{Comprehensively promote the organic integration of family, school and social education}

The development of mass media and the extensive spread of popular culture have led to profound changes in the ideological values of the public, and this change has gradually extended to all aspects of the production and life of the community, forming a special mass cultural effect in society. Therefore, in the process of organizing the ideological and political education of college students, the school should comprehensively analyze the important role of family education, school education and social education, and actively explore the school education, family education and social education of organic integration measures to effectively promote family education , School education and social education synergies play for the students to carry out ideological and political education work to create a good educational environment, and promote the good development of ideological and political education. Under the background of popular culture, colleges and universities should clearly understand that ideological and political education is a systematic project in the process of carrying out ideological and political education. It needs the concerted efforts of all sectors of society, and only the multi-party forces of the society can promote the ideological and political education Optimize the development of college students' ideological values for the good training to provide appropriate support. For school education, the school should actively create a good campus culture on the campus atmosphere, with a specific campus culture and nourish the students' minds, to promote students to consciously resist the erosion of poor culture, enrich the spiritual world of college students [5]. At the same time, the school should also maintain the ideological and political education and teaching work attaches great importance to the ideological and political education and teaching work for the ideological guidance of college students to provide the most basic protection. From the perspective of social analysis, ideological and political education should be combined with all levels and fields of society, the maximum extension of the scope of ideological and political education, and then gradually enhance the influence of social ideological and political education, so that college students in the social life by subtle To promote the ideological and political quality of college students a good training.

\section{Conclusions}

To sum up, in the background of the rapid development of popular culture, colleges and universities in the organization of ideological and political education in the process must be clear that the mass culture of college students have a positive and negative impact, and then in teaching practice to avoid the negative Influence, the positive impact of mining, with the rational application of the popular culture to promote the overall quality of teaching to enhance the overall development of students to provide good support. On the basis of summing up the influence of mass culture on the dual thoughts of college students, this paper makes a comprehensive analysis of the optimization measures of ideological and political education in order to help. 


\section{Acknowledgement}

Project level: school level, project name: Research on Multi-level, Multi-angle and Multi-directional Practice of Ideological and Political Education in Higher Vocational Colleges Project No.: SK201510.

\section{References}

[1] Chen Panyu, Peng Xin, Wang Jingwei, etc. The relationship between popular culture emotion and the effect of ideological and political education, Intelligence, 2016 (26): 179-180.

[2] Wu Xiaofei. Discourse innovation of ideological and political education in the context of mass culture, Labor security world, 2016 (3): 65-66.

[3] Ma Yuan. On the popular culture research on the ideological and political education management of the necessity and significance, Youth years, 2014 (6): 237.

[4] Gao Meng. College of ideological and political education under the background of mass culture, Hebei Normal University, 2015.

[5] Jia Weiwei. The impact of popular culture on ideological and political education, Journal of Kaifeng Institute of Education, 2014 (11): 201-203.

[6] Li Haiyan, Zhang Zhongjiang. The perspective of mass culture under the ideological and political education discourse "change" and "the same", Guangxi Social Sciences, 2015 (2): 206-210. 